\title{
Ignácio Rangel, a correção monetária e o PAEG: recontando a história
}

\section{Fabian Scholze Domingues}

Professor - Universidade Federal do Rio Grande do Sul (UFRGS)

Endereço: Av. João Pessoa, 52. Sala 18 D - Farroupilha - Porto Alegre/RS

CEP: 90040-060 - E-mail:00022523@ufrgs.br

\section{Pedro Dutra Fonseca}

Professor - Universidade Federal do Rio Grande do Sul (UFRGS)

Endereço: Av. João Pessoa, 52. Sala 18 A - Farroupilha - Porto Alegre/RS

CEP: 90040-060 - E-mail: pedro.fonseca@ufrgs.br

Recebido: 09/06/2016. Aceite: 16/03/2017.

\section{Resumo}

A introdução de títulos públicos com cláusulas de indexação e a correção monetária são normalmente atribuídas ao período do PAEG. Em contraste com esta memória histórica, o artigo tem como objeto resgatar que ambas fazem parte de proposta de Ignácio Rangel, a qual foi rejeitada como projeto de Decreto Legislativo enviado ao Congresso Nacional pelo gabinete de Brochado da Rocha, na fase parlamentarista do governo João Goulart. Para tanto, apoia-se em fontes primárias, como os debates no legislativo e entrevistas, para mostrar a antecipação de Rangel nessas importantes medidas institucionais que marcarão a economia brasileira nas décadas seguintes.

\section{Palavras-Chave}

Correção monetária. Indexação. Governo Goulart. Ignácio Rangel. PAEG.

\begin{abstract}
The introduction of indexed government bonds and the monetary correction are usually attributed to the PAEG period of Brazilian economic policy history. In contrast with this historical memory, this paper aims at revisiting the fact that both were part of Ignacio Rangel's proposal, which was rejected by the National Congress during Goulart term. Thus, the research is based on primary sources such as the legislative debates and interviews, in order to show Rangel's pioneering role in regard to these important institutional measures that would impact Brazilian economy in the following decades.
\end{abstract}

\section{Keywords}

Monetary correction. Indexation. Goulart administration. Ignacio Rangel. PAEG.

\section{JEL Classification}

B25. N26.

\footnotetext{
- Agradecemos os depoimentos de Luiz Carlos Bresser-Pereira e Roberto Saturnino Braga, bem como o bolsista do Programa BIC/UFRGS/CNPq Cesar Prazeres Fraga Pereira.
} 


\section{Introdução}

Entre o final da década de 1950 e a metade da década de 1960, a economia brasileira passou por um período de alta inflação. Esta elevou-se de 12,4\% em 1958 para 50,1\% em 1962, até alcançar 89,9\% em 1964 (IBGE, 1987). A explicação acerca das causas do fenômeno e as medidas propostas para enfrentá-lo incrementaram o debate que florescera entre os economistas "monetaristas" e "estruturalistas". Os primeiros seguiam a tradição clássica de associar a alta nos preços à oferta de moeda, então sob a liderança de M. Friedman, com epicentro na Escola de Chicago. Os segundos, principalmente os estudos da Comissão Econômica para a América Latina - CEPAL, respaldados nos trabalhos de J. Noyola (1957), A. Pinto (1958, 1963), C. Furtado (1960), J. Oliveira (1963), O. Sunkel $(1958,1959)$ e R. Prebish (1961, 1962). Estes, embora não compartilhassem de um diagnóstico comum, procuravam relativizar as explicações apoiadas na teoria quantitativa da moeda, preferindo distinguir metodologicamente a diferença entre as causas primárias da inflação e os seus mecanismos de propagação. De qualquer forma, procuravam as raízes do aumento de preços no lado real da economia, como a inelasticidade da oferta agrícola, deterioração dos termos de intercâmbio e pontos de estrangulamento decorrentes do próprio crescimento.

Este artigo não pretende retomar o debate sobre as causas da inflação, já bastante discutido na literatura, ${ }^{1}$ mas enfocar, sobretudo, uma das principais medidas adotadas na área, que marcaria a economia brasileira nas décadas seguintes: a correção monetária. Esta, antes de representar um instrumento de combate à inflação, significou uma medida para conviver com ela, pois pretendia, sobretudo, amenizar suas consequências negativas. Para realizar esta pesquisa, o artigo apoia-se não apenas em fontes secundárias, importantes para contextualizar o debate econômico e a conjuntura histórica em que o mesmo ocorreu, mas também em entrevistas e nos anais do Congresso Nacional, em particular na documentação relativa à apresentação e julgamento do Projeto de Decreto Legislativo (PDL 156), de 1962, defendido por Rangel.

1 As raízes da controvérsia entre duas visões sobre a inflação brasileira encontram-se já no debate entre E. Gudin e R. Simonsen, na década de 1940 (Gudin e Simonsen, 1978). Além dos autores já mencionados, há farta literatura de síntese sobre o debate entre monetaristas e estruturalistas no contexto da economia brasileira, como, por exemplo: Lopes (1979), Barbosa $(1983,1987$, 1997) e Simonsen e Cysne (1989). 
Dentro da temática proposta, visa-se trazer à liça as contribuições deste autor para os temas da correção monetária e das alternativas de financiamento da economia brasileira que se apresentavam naquela quadra histórica, as quais são pouco lembradas. O fato de a correção monetária ter-se firmado institucionalmente como umas das principais medidas institucionais do Programa de Ação Econômica do Governo (PAEG), durante o governo militar de Castelo Branco, contribuiu para a associação entre ambos, a qual ficou consagrada na memória histórica.

Entre os diversos expoentes da literatura econômica que contribuem para tal percepção da memória histórica, apresentamos a seguir diversas passagens que a reforçam. Roberto Campos, ao apresentar as reformas protagonizadas pelo PAEG, afirma que "a correção monetária, tal como originalmente concebida, era um animal inteiramente diferente do que veio a existir após 1980" (Campos, 1994, p.642, itálicos acrescidos), concedendo sub-repticiamente aos formuladores do PAEG a originalidade de sua criação. Em sua obra em coautoria com Simonsen, sobre o PAEG e a história da correção monetária no Brasil, Campos escreve: "Embora numa inflação crônica e violenta os reajustes de preços e salários acabem por se tornar mais ou menos automáticos, a indexação, isto é, a revisão periódica de preços por autorização legal e com base no comportamento de índices preestabelecidos, era pouco comum no caso brasileiro antes de 1964. De fato, o único caso de reajuste automático facultado pela lei era a correção monetária do ativo imobilizado das empresas, instituída pelo art. 57 da Lei 3.470 de novembro de 1958" (Simonsen e Campos, 1974, p.131, itálicos acrescidos).

Já Werner Baer trata do assunto afirmando: "O novo governo iniciou a experiência com a indexação porque os responsáveis pela política econômica achavam que a inflação não poderia ser controlada imediatamente". Na sequência, apresenta a introdução da indexação, mediante citação dos dispositivos legais, nas quatro áreas de abrangência do PAEG, finanças públicas, financiamento das empresas, sistema financeiro da habitação e "poupança forçada"(Baer, 1985, p.362 - 363). Na análise das realizações da indexação, Baer resume sua visão sobre o uso da indexação no Brasil, afirmando que "do ponto de vista de seu propósito original, a experiência brasileira de indexação financeira parece ter sido pelo menos um sucesso qualificado". O autor atribui, assim, ao PAEG - por ser ele o referente da expressão "experiência brasileira de indexação" - o início do uso de instrumentos de indexação financeira. Assim como Simonsen e Campos, Baer não faz qualquer menção às propostas anteriores de correção monetária, como a de Rangel. 
Lara Resende segue a mesma direção e afirma: "A convicção da necessidade de reformas institucionais acompanhou o PAEG desde seu diagnóstico. Três áreas foram particularmente destacadas, refletindo, acertadamente, a percepção do governo a respeito dos pontos de estrangulamento institucionais da economia: primeiro, a desordem tributária; segundo, as deficiências de um mercado financeiro subdesenvolvido e a inexistência de um mercado de capitais; e, por último, as ineficiências e as restrições ligadas ao comércio exterior. Por trás das três áreas de desordem institucional estava, sem sombra de dúvida, a incompatibilidade entre o pressuposto da moeda estável e as altas taxas de inflação. Num claro reconhecimento de que não se esperava que a estabilidade de preços fosse alcançada no médio prazo, o mecanismo de correção monetária foi introduzido" (Resende, 1990, p.229).

O artigo pretende resgatar não só o fato de que essa história é mais complexa, mas o fato de Rangel, já antes, em 1962, ter elaborado projeto semelhante, embora com recurso a arcabouço teórico bastante heterodoxo, diferente do diagnóstico de inflação presente no PAEG ${ }^{2}$ Para Rangel, a inflação era consequência da capacidade ociosa, que, sendo endêmica na economia brasileira, não podia ser facilmente debelada. Dessa maneira, a correção monetária era mais do que um meio de conviver com a inflação; era uma forma de viabilizar o financiamento interno dos investimentos - um ponto que é central na obra de Rangel. Já o PAEG tendeu a mesclar medidas ortodoxas, como rebaixamento de salários reais, corte nos gastos públicos e altos juros, com heterodoxas, dentre as quais a concepção de inflação como fenômeno não apenas monetário, mas resultado de conflito distributivo. Além disso, aceitava conviver com certa inflação com o propósito de compatibilizar seu combate com crescimento do PIB, o que o afasta da ortodoxia econômica da época e mais lembra o receituário cepalino.

Embora seja comum o equívoco apontado acima de se considerar os primeiros mecanismos de correção monetária na economia brasileira como tendo sido implementados somente pelo PAEG (com exceção da correção de ativos levantada por Campos e que será tratada na seção $3)$, a polêmica sobre os problemas decorrentes das perdas inflacionárias, seja na cobrança de impostos, seja para a estruturação do mercado de títulos, foi intensa entre economistas e parlamentares nos dez anos precedentes ao plano econômico dos militares, pois essas perdas implicavam o virtual esgotamento das fontes de financiamento da economia

2 Outros aspectos correlatos ao tema serão abordados no correr do artigo, mas faz-se mister referir, neste sentido, os tradicionais artigos de Martone (1975), Ianni (1977) e Resende (1989). 
brasileira. Assim, à guisa de introdução, inicialmente procuraremos reconstruir brevemente a discussão que se fez nesta quadra histórica sobre a utilização de mecanismos de correção monetária - como a que envolve a reavaliação de ativos fixos e a proposta dos empréstimos voluntários de Moreira Salles - para, em seguida, analisar em detalhe a proposta de Rangel para a constituição de um fundo de títulos públicos com reajuste monetário. Recupera-se, aqui, como fonte primária de pesquisa, o debate legislativo envolvido quando seu projeto foi enviado ao Congresso Nacional. A seguir, compara-se o mesmo com as propostas do PAEG, pois somente com este ocorreu a implantação dos mecanismos de correção monetária na economia brasileira.

Cabe lembrar, em benefício da exposição, que o PDL 156 de Rangel foi apresentado no governo Goulart, no período parlamentarista, sob notória conturbação política, enquanto a Lei 4.357 do ministro Bulhões foi proclamada após 1964, portanto, em situação de autoritarismo e sem as pressões e concessões presentes numa democracia. O período parlamentarista iniciou com o gabinete chefiado por Tancredo Neves e com o banqueiro Moreira Salles na condução da política econômica. Dois planos foram lançados por Moreira Salles durante sua administração, imediatamente anteriores à proposta de Rangel: o Plano de Emergência, apresentado em meados de novembro de 1961, e o Plano de Economia, de março de 1962. Este último foi discutido e aprovado pelo Parlamento, inclusive com a possibilidade de lançamentos de títulos com correção monetária, numa proposta, que, como veremos, embora antecipe a de Rangel em alguns aspectos, em outros dela difere. Além disso, não chegou a ser executada, em função da queda do gabinete de Tancredo Neves em junho de 1962 e da renúncia de Moreira Salles em setembro de 1962. Já a proposta de Rangel surgiu no arcabouço da agenda de reformas e da solicitação da delegação de poderes feita por Brochado da Rocha, que, no entanto, sofreu forte oposição dentro do Congresso Nacional, sendo considerado por alguns setores como "inaceitáveis" (Loureiro, 2012, p.298). As solicitações de delegação de poderes foram rejeitadas em sua maioria pelo Congresso Nacional, provocando a renúncia de Brochado com apenas três meses de mandato e o aprofundamento da crise política. Como consequência da crescente oposição ao governo João Goulart dentro do Congresso Nacional, que culminaria na antecipação do plebiscito presidencialista, o projeto de Rangel não foi aprovado na Comissão Parlamentar instituída para apreciá-lo. Novas condições políticas para apreciação de temas econômicos somente estarão presentes após o plebiscito presidencialista, já no ano de 1963. 
A inflação crescente verificada ao longo da década de 1950 e agravada na primeira metade da década seguinte desestabilizava as contas públicas, dificultava a cobrança de impostos e virtualmente impedia a criação de poupança e a realização de financiamentos de longo prazo. Os juros praticados frequentemente eram negativos - uma vez que vigorava a Lei da Usura e as perdas inflacionárias ultrapassavam a taxa máxima de juros permitida em lei ( $12 \%$ ao ano) - de modo que a concessão de créditos bancários era restrita e claramente insuficiente para manter as taxas de crescimento almejadas pelos governos, então fortemente marcados pelo ideal desenvolvimentista. Dentro deste quadro, o financiamento para importação de bens de capital também ficava prejudicado, seja pela depreciação da moeda nacional, seja pela impossibilidade de financiamentos de longo prazo, com impacto negativo no setor de bens de capital.

Em 1962, o economista Ignácio Rangel - com um longo histórico de participação no governo, trabalhando no BNDE no momento em tela - encabeçou uma comissão responsável pela proposição de um Projeto de Decreto Legislativo, o PDL 156, que buscava inserir mecanismos de correção monetária para atacar de forma articulada o problema inflacionário nas contas públicas e nos mecanismos de financiamento da economia brasileira, sugerindo a organização de um fundo a partir de recursos da poupança privada para induzir investimentos de longo prazo. Essa proposta legislativa baseava-se nos estudos de Rangel sobre a inflação brasileira, que serão apresentados em uma de suas principais obras, A Inflação Brasileira, de 1963. Mais tarde, já na fase presidencialista do governo Jango, em fevereiro de 1964, Rangel também foi convidado por Goulart para assumir um cargo no governo. Todavia, em sua percepção, deixando em aberto se seria o Ministério Extraordinário do Planejamento ou a Superintendência da Moeda e do Crédito (Faro e Sinelli, 2014, p.138). Rangel, talvez por perceber as dificuldades políticas para viabilizar mudanças de rumos na política econômica, recusou o convite.

O PDL 156, embora tenha sido rejeitado na Comissão Parlamentar, trouxe à luz nova perspectiva - baseada na discussão dos coevos - sobre os mecanismos de financiamento da economia brasileira e sobre a própria correção monetária, temas fundamentais para compreensão dos problemas econômicos do período. Destarte, somente em 1964, com o governo militar, a questão da correção monetária voltaria à discussão parlamentar, com a Lei 4.357/1964, que instituiu as Obrigações Reajustáveis do Tesouro Nacional (ORTN), com profundas implicações 
no mercado de trabalho e na cobrança de impostos, bem como na indexação da economia brasileira como um todo. Como o PDL 156 de Rangel e a Lei 4.357/1964 de Bulhões visavam à criação de mecanismos de correção monetária, iremos inicialmente apresentar o contexto teórico do período sobre os diagnósticos acerca da inflação e da adequação e limites dos mecanismos de correção monetária implicados pelos respectivos diagnósticos.

\section{O debate teórico sobre a inflação e os mecanismos de correção monetária}

Como já foi mencionado, o debate teórico sobre a inflação e a conveniência da correção monetária perpassa a década de 1950, com duas correntes de pensamento contribuindo para a compreensão do fenômeno inflacionário no sistema econômico e suas consequências: os monetaristas e os estruturalistas. Se considerarmos tais correntes como expoentes de campos teóricos divergentes e frequentemente opostos, perceberemos que a criação de mecanismos de correção monetária tornou-se um consenso teórico ao longo das décadas de 1950 e 1960 à medida que as taxas de inflação se aceleravam e que não eram acompanhadas por crescimento econômico. Tratava-se de típica estagflação, que se impôs à investigação teórica após uma década de crescimento mundial calcado em políticas keynesianas. A estagflação ainda não havia sido suficientemente compreendida em suas causas e em seus mecanismos de transmissão, como é possível depreender das linhas gerais do debate apresentado de forma esquemática a seguir entre monetaristas e estruturalistas. Rangel, como veremos, é um dos primeiros e mais destacados teóricos na análise desse fenômeno, que o distingue das correntes principais do pensamento econômico dominantes, mostrando certa "independência" em relação aos dois lados em embate (Bielschowsky, 2004, p.209).

Em 1974, Friedman lançara um pequeno livro no qual sintetizou sua visão acerca da correção monetária amadurecida na década anterior, intitulado Monetary Correction. Embora os custos da inflação já fossem abordados pela literatura econômica, as formas de propagação dos reajustes inflacionários eram menos estudadas. Friedman defendia, então, que a correção monetária seria o melhor meio de mitigar os efeitos 
colaterais da inflação. Ao analisar a situação da Inglaterra no início da década de 1970, considerava que o país deveria usar os mecanismos de indexação que se mostraram efetivos no Brasil, Canadá e Israel (Friedman, 1974, p.30). Para o autor, o atraso nos repasses de preços distorceria os preços relativos, a estrutura da produção e o nível de emprego. Com a introdução de mecanismos de correção monetária como cláusulas contratuais, esses efeitos colaterais poderiam ser substancialmente reduzidos. O uso de indexadores por eles mesmos - argumenta Friedman - não acelera nem diminui a inflação, mas somente facilita a sua transmissão e minimização. Para ele, os contratos privados com indexadores deveriam ser voluntários, isto é, de livre adesão das partes, e garantidos (enforced) pelo governo à medida que fossem usados de maneira consensual. Neste aspecto, destacamos adiante, na contramão dos preceitos de Friedman, o estudo do uso de fundos compulsórios e de mecanismos de correção monetária ainda no governo João Goulart.

Nesta concepção, a inflação continuada e persistente no longo prazo é sempre um efeito monetário, que resulta de uma expansão mais rápida da base monetária do que do produto. O economista de Chicago, contudo, considera que a taxa exata não é facilmente previsível ou diretamente relacionada, dependendo de outros fatores, como taxa de crescimento da economia, da poupança e do investimento. Desse modo, Friedman não se opõe ao uso de indexadores para evitar a perda real dos valores monetários, considerando que o uso é neutro do ponto de vista da taxa de inflação. A principal objeção para a ampliação do uso de indexadores na economia é o fato de que a indexação tem um impacto inflacionário na economia. Para o economista de Chicago tal objeção - tomada sem restrições - é simplesmente falsa, pois a indexação é resultado da inflação e não o contrário (Friedman, 1974, p.30). O indexador, sustenta, faz com que a inflação seja transmitida mais rapidamente, mas não aumenta a velocidade de crescimento (ou decrescimento) da taxa inflacionária.

Friedman (1974, p.32) reconhece que a inflação é um dos principais motivos de intranquilidade política, tendo contribuído, por exemplo, para o fim do governo de Salvador Allende no Chile, mas que não é fácil acabar com ela, pois o custo social de uma parada abrupta no reajuste geral de preços é muito grande, uma vez que implica reduzir a atividade econômica e os níveis correspondentes de emprego dos fatores, em particular do trabalho. Friedman adverte que a insistência em tentar acabar com a inflação de maneira sumária pode gerar severa depressão. Desse modo, sustenta, as cláusulas de indexação podem não ser a me- 
lhor solução, mas não se conhece outra forma de minimizar as perdas inflacionárias.

Já a escola estruturalista, com o respaldo institucional da CEPAL, por sua vez, tinha na visão de Rangel uma vantagem em relação aos monetaristas, pois entendia que a expansão monetária era um epifenômeno, com "origem no bojo da economia e não no gabinete do Ministro da Fazenda" (Rangel, 1963, p.27). Ou seja: a inflação teria origem nas condições reais dos mercados, em suas estruturas e no poder de mercado dos agentes, e não nas emissões de moeda do governo. Os estruturalistas explicavam, assim, a elevação autônoma dos preços pela existência de pontos de estrangulamento na economia, notadamente pela insuficiência da capacidade para importar e pela inelasticidade da oferta no setor agrícola. Desse modo, Rangel afirma (1963, p.23):

Noutros termos, o problema estaria na estrutura do sistema econômico - donde o nome da escola - ou, para usar a expressão dos economistas marxistas, na composição natural do produto social. A explicação é exaustiva, pondo ponto final à pesquisa, pois a partir daí, restaria apenas aprofundar o estudo setorial da economia e preparar esquemas para dar a esta uma estrutura mais condizente com a estrutura da demanda.

Todavia, ao identificarem a origem da inflação na estrutura produtiva, os estruturalistas esqueciam-se, conforme Rangel, de seus aspectos monetários, embora reconhecessem sua origem no funcionamento do sistema capitalista. Mas a questão monetária não poderia ser deixada de lado: a equação das trocas "nada tem de direitista ou de esquerdista, porque antes de haver sido formulada por Fischer já havia sido formulada por Marx" (Rangel, 1963, p. 23).

Como é possível depreender das considerações acima, Rangel acompanhava o debate teórico entre monetaristas e estruturalistas e tomou o seu próprio partido, trazendo compreensão para aspectos importantes do fenômeno inflacionário, presente em artigos como Recursos ociosos na economia nacional, de 1960 e a sua obra maior, $A$ inflação brasilei$r a$, de 1963. Cumpre ressaltar que esta última foi publicada logo após a discussão legislativa em que esteve envolvido, objeto em tela deste 
trabalho. Já no prefácio do livro, ao explicar como se aplicou ao estudo da inflação brasileira, Rangel afirma:

Ao aprofundar a matéria, surpreendeu-me a superficialidade com a qual as duas correntes em pugna a travavam... A pedra de toque para avaliar essas duas teorias é a capacidade ociosa. As duas escolas a negam, aberta ou sub-repticiamente. Embora a acumulação de capacidade ociosa seja um fato empiricamente demonstrado, as duas correntes estudam a emissão como o ato inicial de um processo conducente à expansão da demanda global do sistema. Ergo, se houvesse capacidade ociosa em condições de ser utilizada - $e$, sem isso, deixai-me que acrescente, não há capacidade ociosa -, essa expansão da demanda global conduziria a uma expansão da renda, e não a uma elevação de preços (Rangel, 1963, p.13).

Como veremos adiante, tal argumento é central para a compreensão das razões anti-inflacionárias do PDL 156 proposto por Rangel e, ao que tudo sugere à primeira vista, incompreendidas pelos parlamentares, uma vez que visava a induzir o aumento do investimento e a diminuição da capacidade ociosa, provocando aumento da renda e diminuição das taxas inflacionárias.

Segundo Rangel, os monetaristas confundiam causa com efeito. Como frisa Bresser-Pereira (In: Rangel, 1978, p.7-11), para ele é "a variação autônoma do nível de preços (que pode resultar da variação dos preços de alguns produtos não compensada pela variação, em sentido inverso, dos preços dos demais) que leva o governo, passivamente, a emitir moeda". Assim, de maneira precoce, Rangel estabeleceu as bases da teoria endógena da oferta de moeda. Os estruturalistas teriam percebido, em seu entender, tal caráter endógeno, mas comungariam com os monetaristas o equívoco de interpretar a inflação brasileira como de demanda. Para Rangel, ao contrário, no país havia insuficiência crônica da demanda, dada a má distribuição da renda, derivada da estrutura agrária baseada no latifúndio e no desemprego da mão de obra. Assim, a alta taxa de exploração causada por esses fatores implica uma baixa propensão a consumir. A consequência é a capacidade ociosa em diversos e amplos setores da economia, capacidade ociosa essa que monetaristas e es- 
truturalistas não detectavam, dada sua teoria de inflação causada por excesso de demanda.

Rangel possuía uma visão histórica da economia brasileira, que levava em consideração a existência tanto de ciclos de longo prazo (ou de Kondratieff), determinados exogenamente, como de ciclos endógenos de acumulação (Juglar). A partir desta perspectiva, o autor trata da instituição da correção monetária, dentro de um quadro mais geral das possibilidades de evolução do capitalismo brasileiro, que envolviam uma preocupação de fundo com o problema do financiamento. No ciclo anterior (década de 1950), as Instruções da SUMOC foram essenciais ao arranque da economia brasileira ao criar os chamados mercados de câmbio no país. Essas ideias aparecem já em 1957, no artigo Dualidade Básica da Economia Brasileira (Rangel, 1957, p.285), depois retomadas em A Dinâmica da Dualidade Brasileira (Rangel, 1962, p.552). É interessante lembrar que, mais tarde, após o período em tela neste trabalho, Rangel argumentará, da mesma forma, que no ciclo posterior (final da década de 1970/início da de 1980), mudanças institucionais dada a perda de capacidade de financiamento do Estado - deveriam ser encampadas no sentido de criar condições para a maior participação do setor privado nacional no enfrentamento do nó infraestrutural, assim como do aparelhamento de intermediação financeira capaz de mediar a transferência intersetorial de recursos (Rangel, 1982).

A inflação no início da década de 1960 tinha origem num duplo processo na perspectiva do autor. Por um lado, grandes empresas, como as que controlam a comercialização de produtos agrícolas, organizam-se na forma de oligopólios ou cartéis, passando a aumentar os preços de maneira autônoma, como forma de defender seus lucros da insuficiência de demanda. O processo começa no setor agrícola, estendendo-se ao setor industrial e serviços públicos. A inflação surge como um mecanismo de defesa do sistema econômico, sendo principalmente administrada ou de custos, e não de demanda.

Por outro lado, a economia não entra em colapso apesar da insuficiência de demanda devido aos reajustes inflacionários. Considerando a baixa propensão a consumir presente na economia brasileira, a demanda agregada é compensada por uma elevada taxa de imobilizações. Os empresários e indivíduos se protegiam da inflação imobilizando o máximo possível, evitando reter ativos líquidos. Nesse processo, o governo é mero agente passivo do aumento de moeda em circulação dados os aumentos 
de preços. Realizando emissões, o governo cobre seu próprio déficit causado pelos aumentos autônomos de preços e por sua incapacidade política de aumentar a carga tributária. Desse modo, a inflação também funciona novamente como um mecanismo de defesa da economia.

Dessa maneira, a solução ao problema dada por Rangel diferia fundamentalmente das noções monetaristas, de redução dos gastos governamentais, e das noções estruturalistas, pois implicava o aumento da utilização da capacidade instalada como forma de gerar renda, que, de outra forma, era criada de forma autônoma e inflacionária pelos cartéis e oligopólios dominantes na economia brasileira.

\section{Os debates sobre a correção monetária}

Ao analisar a discussão sobre a correção monetária no Brasil do ponto de vista histórico, é possível traçar diferentes linhas de debate ocorridas nas instâncias governamentais sobre a necessidade de criação de mecanismos para manutenção dos valores reais dos ativos ao longo da década de 1950 e início dos anos 1960. As discussões tratam, sobretudo, de questões tributárias e de financiamento do Estado. A discussão sobre títulos indexados já estava presente no Plano de Economia de Moreira Salles, que visava aumentar as receitas do governo, mas essa discussão é relativamente independente daquela provocada por Rangel, que tinha uma visão diferente sobre os objetivos da correção monetária em sua proposta.

Um dos grandes debates sobre a correção monetária do período versava sobre a necessidade de atualização dos preços dos bens fixos das empresas, uma vez que a rápida defasagem dos valores em razão das perdas inflacionárias dificultava cálculos contábeis relativos à depreciação e à cobrança de impostos, implicando a perda real dos valores tributados. Do ponto de vista tributário, a questão não era nova, remontando a previsão de possibilidade de avaliação dos ativos empresariais ao Decreto Lei n ${ }^{\circ} 7.390$, art. 53, seção I, de 1926. A legislação posterior autorizou temporariamente e dentro de certos limites a reavaliação de ativos fixos com alívio fiscal (Leis 154 de 1947 e 1.474 de 1951). Já a Lei federal 2.862, de 1956, introduziu para os exercícios fiscais de 1957 a 1960 um imposto sobre lucros extraordinários, isto é, sobre lucros que excedes- 
sem 30\% do capital real aplicado ao negócio. Concomitantemente, esta lei permitia o aumento do capital acionário registrado por meio da reavaliação dos ativos fixos. Então, a mencionada Lei 3.470 por Simonsen e Campos, de 1958, criou a "correção monetária" para ativos fixos. Conforme Tilbery $(1983,162)$, a correção monetária constituía um dispositivo opcional que poderia ser aplicado a cada dois anos e que estava baseado em indexadores oficiais. Esta forma de correção monetária era inteiramente diferente da reavaliação de ativos. O aumento crescente da correção monetária de ativos fixos, depois da dedução das variações cambiais e monetárias (mais tarde restrita àquelas originadas no financiamento de ativos fixos), estava sujeito, pela Lei 3.470 de 1958, a um imposto de renda de $10 \%$. Neste período, a depreciação de ativos fixos baseada na correção monetária ainda não era permitida. Portanto, um dos principais objetivos do ajustamento dos livros contábeis dos ativos fixos ainda não havia sido alcançado. Somente em 1964 o problema da não depreciação de ativos fixos reavaliados por indicadores de correção monetária seria resolvido pela legislação, de modo que a Lei 4.375 transformou a instituição de correção monetária para ativos fixos numa obrigação legal para as empresas, a ser realizada num período de até 120 dias após a publicação do Balanço Anual.

O outro grande debate sobre a correção monetária versava sobre a introdução de títulos indexados. A discussão da criação de títulos indexados estava relacionada ao esgotamento das fontes de financiamento da economia brasileira. A primeira proposta teve origem no âmbito do Poder Executivo no primeiro semestre de 1962: o Plano de Economia de Moreira Salles. Neste constava como uma de suas propostas principais a colocação de títulos indexados no mercado, a qual se esperava que fosse se materializar na Lei Orgânica do Crédito Público (março 1962). ${ }^{3}$ Por conseguinte, não só a proposta de Rangel diferia daquela que seria adotada no período do PAEG, como esta já havia sido antecipada de certa forma, embora de forma parcial, durante o período parlamentarista do governo Goulart pelo ministro Moreira Salles, apesar de não ter sido implementada devido à dissolução do gabinete de Tancredo Neves e a posterior renúncia de Moreira Salles. ${ }^{4}$ Ainda assim, o executivo possuía autorização para o lançamento desses títulos com desconto de face, em

3 Conforme Loureiro (2012, p.234): "Em março de 1962, o gabinete Tancredo Neves enviou ao Legislativo os projetos de criação do empréstimo compulsório, de regulamentação do lançamento no mercado de títulos públicos indexados à inflação e do reajuste salarial do funcionalismo em 40\%".

4 Temos consciência de que o momento político é muito delicado e seu tratamento em detalhe fugiria ao escopo deste trabalho, de modo que o foco do artigo não é esse. Atemo-nos aqui apenas à discussão sobre a interface pensamento econômico/policy. 
índice calculado pelo Conselho Nacional de Economia (o mesmo índice que será usado no PAEG).

O Plano de Economia de Moreira Salles - segundo plano econômico do período parlamentarista, o primeiro havia sido o Plano de Emergência previa o lançamento de títulos indexados (que será aludido mais adiante por Daniel Faraco, relator do PL apresentado por Rangel) no montante autorizado de $\mathrm{Cr} \$ 130.000 .000$, que, apesar de licença parlamentar, não haviam sido utilizados. O Plano de Economia concebido por Moreira Salles observava metas rígidas na contenção de gastos, adiamento de dispêndios, elevação das receitas por meio de empréstimo compulsório e criação de um empréstimo voluntário, constituído por títulos de dívida pública com correção monetária mediante desconto de face, com o objetivo de gerar receitas ao governo (Loureiro, 2012, p.226). A criação desse empréstimo voluntário foi criticada por setores empresariais importantes, como a Confederação Nacional da Indústria (CNI) e a Federação das Indústrias de São Paulo (FIESP). ${ }^{5}$ Além desta oposição, havia a questão política de que o Conselho de Ministros não seguiu o plano econômico em sua essência contracionista, por não conseguir impedir reajustes salariais aos funcionários públicos e a continuação do esquema de financiamento do café. Em suma, o plano foi malsucedido e a proposta de um "empréstimo voluntário" com correção monetária foi abandonada devido à resistência oriunda de setores empresariais, embora ainda contasse com a necessária anuência legislativa. Conforme Loureiro, a lei seria aprovada em 11 de junho de 1962, mas "o gabinete de Tancredo Neves já havia anunciado sua renúncia, levando ao abandono da meta de colocação desses títulos no mercado" 6 (Loureiro, 2012, p.238, nota 170).

5 No caso específico da CNI, conforme Loureiro (2012, p.228): "segundo a CNI, a restrição ao crédito e a colocação de títulos públicos indexados à inflação tenderiam a "carrear poupanças do setor privado", deprimindo investimentos. Como alternativa a essas medidas, propôs-se uma abordagem "gradualista" de combate à inflação (três a quatro anos), o que permitiria uma flexibilização das metas de austeridade contidas no programa."

6 Loureiro explicita as razões que levaram ao abandono do Plano de Economia: "O abandono do Plano de Economia começou, efetivamente, em junho de 1962, intensificando-se nos três meses seguintes. O desequilíbrio das contas públicas, por exemplo, experimentou forte escalada em julho (...). O mesmo pode-se dizer sobre a oferta de crédito do Banco do Brasil ao setor privado, que ultrapassou a meta nominal do ano (Cr\$ 35 bilhões) também em julho, mas que já havia saído do controle no mês anterior. O total de meios de pagamento, por sua vez, teve em agosto seu mês de maior crescimento real (4\%). Até mesmo o objetivo de lançar títulos indexados à inflação para cobrir os gastos do governo - medida considerada primordial por Moreira Salles - deixou de ser discutido de junho em diante, sinalizando a possibilidade de um sério descontrole do déficit público em 1962. A partir daqui, portanto, sob todos os ângulos, a evolução dos indicadores macroeconômicos demonstrava que o Plano de Economia já havia se transformado em uma peça do passado." 
Dentro deste complicado contexto político, já no gabinete de Brochado da Rocha, surge o debate coordenado pelo economista Ignácio Rangel durante o ano de 1962, sintetizado no PDL 156, que pretendia usar títulos com desconto de face para criar um fundo de estabilização do comércio exterior e do desenvolvimento. ${ }^{7}$ A aceitação de Brochado da Rocha colocou fim a uma aguda crise política que durara duas semanas. Seu gabinete destinou suas energias para a antecipação do plebiscito presidencialista, questão na qual se saíra vitorioso, enquanto que o Congresso Nacional lhe fazia forte oposição nas matérias de interesse do Poder Executivo.

É importante salientar que a proposta de Rangel diferia do empréstimo voluntário proposto por Moreira Salles, pois não pretendia somente aumentar as receitas do governo, numa típica política econômica ortodoxa, tendo como atrativo o lançamento de títulos que repunham a perda inflacionária, mas buscava criar mecanismos de desenvolvimento econômico de longo prazo, utilizando a correção monetária como instrumento, a partir de um diagnóstico altamente elaborado da inflação brasileira e de suas causas, como já apresentamos na seção 2 deste trabalho. A proposta de Rangel - complexa em seus objetivos econômicos - entrementes, não foi autorizada na Comissão Parlamentar devido à oposição política, cujo delicado contexto sumarizamos acima, e aos receios verbalizados pelos deputados da oneração que o PDL 156 poderia proporcionar aos cofres públicos, agravando a inflação.

Em suma, a discussão do projeto ocorreu na fase parlamentarista do governo Goulart, a qual foi marcada por forte oposição política, uma vez que houvera veto militar à posse de Goulart, só revertido após a campanha da Legalidade, liderada por Leonel Brizola. ${ }^{8}$ Também foi um

7 O gaúcho Brochado da Rocha foi o terceiro indicado por Jango para substituir Tancredo Neves, o que, de certa forma, mostra a gravidade da crise política. O primeiro, recusado pelo Congresso, havia sido Santiago Dantas, o segundo, que renunciou misteriosamente ao cargo em 24h, Auro de Moura Andrade.

8 As dificuldades e meandros da conjuntura política não são objeto deste trabalho, embora a rejeição do projeto de Rangel deva ser entendida nesse contexto político. É vasta a literatura sobre o contexto político do governo João Goulart e suas implicações na política econômica. Vale, neste aspecto, mencionar: Bandeira, Moniz. O Governo João Goulart: as Lutas Sociais no Brasil, 1961 1964. Rio de Janeiro, Civilização brasileira, 1977. Castelo Branco, Carlos. Introdução à Evolução de 1964. Rio de janeiro, Artenova, 1977. Fonseca, Pedro C. D. "Legitimidade e Credibilidade: Impasses da Política Econômica do Governo Goulart". In: Estudos Econômicos, São Paulo, USP, v. 34, n. 1(93), 2004, p. 587-622. Fonseca, Pedro C. D. e Monteiro, Sérgio M. "Credibilidade e Populismo: a Política Econômica dos Governos Vargas e Goulart”. In: Revista Brasileira de Economia. Rio de Janeiro, 59(2), abr/jun 2005, p. 215-243. Moreira, Cássio S. O Projeto de Nação do Governo João Goulart: o Plano Trienal e as Reformas de Base (1961-1964). PPGE/UFRGS, 2011 (Tese de Doutorado). Loureiro, Felipe Pereira. Empresários, Trabalhadores e Grupos de Inter- 
dos seus momentos mais críticos, acirrado quando o primeiro-ministro Brochado da Rocha demandou uma delegação de poderes para vários temas. Brochado sairia derrotado em vários desses pedidos de delegação, o que o levaria a sua renúncia no início de setembro de 1962, agravando ainda mais a forte crise política no país. Desse modo, a partir de janeiro de 1963 é que seriam recriadas as condições mínimas para a gestão da política econômica, que resultariam no Plano Trienal de Celso Furtado (Loureiro, 2012, p. 244). Somente com o golpe militar a discussão sobre o uso de mecanismos de correção monetária para organizar as contas públicas e promover o financiamento de longo prazo da economia foi retomada e efetivamente implementada, em moldes diferentes daqueles propostos por Rangel, em particular por prever reajustes através do uso de indexadores de correção monetária e não mais descontos de face nos títulos. Os mecanismos de correção monetária desempenharam importante papel no assim chamado "milagre" econômico ocorrido no Brasil ao final da década de 1960 e início da década de 1970 (Tilbery, 1983, p. 164).

Frente aos problemas de financiamento enfrentados pela economia brasileira no início dos anos 1960 - que agudizavam a crise política - o governo João Goulart submeteu à apreciação do Congresso Nacional o PDL 156, publicado no Diário do Congresso Nacional em 16 de agosto de 1962. Este PDL visava a delegar ao Executivo o poder de decretar lei autorizando a União a emitir títulos até o montante de 200 bilhões de Cruzeiros para constituição de um Fundo de Desenvolvimento e Estabilização do Comércio Exterior. Pela proposta, este fundo seria administrado por um ou vários dos bancos de investimento em controle da União, com seus recursos divididos em duas parcelas iguais.

Os recursos levantados pela proposta legislativa a partir da venda de títulos com desconto de face seriam destinados a atacar duas das áreas com maiores problemas de financiamento: os projetos de desenvolvimento estatais e as importações de bens de capital. Conforme o PDL 156, uma parcela dos recursos seria destinada a "suprir recursos financeiros como antecipação de receita, à União, aos estados ou às entidades a eles subordinadas e que disponham legalmente de recursos vinculados

esse: a Política Econômica nos Governos Jânio Quadros e João Goulart, 1961-1964, IFCHL/USP, 2012 (Tese de Doutorado). Munteal, Oswaldo et alii (org.). O Brasil de João Goulart; um projeto de Nação. Rio de Janeiro: PUC/Rio: Contraponto, 2006. Ferreira, Marieta de Moraes (org.). João Goulart: entre a Memória e a História. Rio de Janeiro, Editora FGV, 2006. Ferreira, Jorge e Gomes, Ângela de Castro. 1964: o golpe que Derrubou um Presidente. Rio de Janeiro, Civilização Brasileira, 2014. 
à execução de seus programas de desenvolvimento". E a outra parcela, destinada a "financiar operações destinadas a reduzir o déficit das operações correntes de comércio exterior, estimulando a reorientação das importações de acordo com as conveniências cambiais do país". Desse modo, com uma mesma proposta legislativa, Rangel pretendia aliviar os problemas de financiamento tanto do setor público - alinhando-se ao projeto desenvolvimentista em sua dimensão estatal - quanto do setor privado - permitindo o financiamento dos setores mais dinâmicos da economia, ligados ao comércio internacional - através da criação de um mecanismo de captação de poupança privada.

Na justificativa ao PDL 156, que trata do conteúdo, objeto e alcance da delegação pretendida pelo poder executivo, são arroladas quatro justificativas. A primeira justificativa, dividida em três motivos, é que a transferência da atribuição legislativa visava a "dar início numa ocorrência em que o problema se apresenta excepcionalmente maduro, à reestruturação do mercado de capitais" (PDL 156). Tema enfatizado na discussão legislativa como uma prioridade para Rangel, que já havia dado um passo importante em 1956 com a reestruturação do mercado de títulos e que está novamente em pauta no ano 1962 com uma segunda grande reestruturação dos títulos da dívida pública, como veremos adiante. O segundo motivo aventado em favor do PDL 156 era que a constituição do Fundo visava a "prover recursos ao Poder Público que o libertem parcialmente... a recorrer sem medida às emissões do meio circulante ou a expansão do déficit". Estratégia que permitiria expandir a base monetária sem aumentar as emissões, de modo a criar crédito sem a pressão inflacionária correspondente. Já o terceiro motivo consistia em "facultar a numerosas empresas públicas ou privadas títulos seguros e de suficiente rentabilidade, que as habilitem a renunciar sem prejuízo às praxes socialmente ruinosas de acumular instalações, estoques e outros itens do seu imobilizado e do seu realizável superiores a suas efetivas necessidades". Este terceiro motivo permite uma compreensão mais geral do problema em foco, que se tratava não apenas da criação de um mecanismo de financiamento, como também - na visão de seu mentor - de um mecanismo anti-inflacionário. Como já vimos, Rangel desenvolveu em A Inflação Brasileira o argumento de que as empresas nacionais mantinham preços altos e grande capacidade ociosa como maneira de se proteger da inflação, ação que, considerada no agregado, agravava o problema da inflação sem crescimento econômico. Por fim, a quarta justificativa ao PDL 156 argumentava que "impõe-se, portanto, a organização da poupança privada... Ora, essa poupança será ampliada, por 
isso mesmo que o resultado final de toda a operação que se visa a instrumentalizar implica ampliação das vendas e, portanto, da receita, em medida desproporcionada com incremento da receita, à vista da massa de capacidade ociosa ora acumulada no interior da economia brasileira". Esta justificativa expressa com clareza a concepção desenvolvimentista de Rangel, já que a chave para a solução dos problemas de financiamento da economia residia no aumento da capacidade de investimento e na diminuição da capacidade ociosa, ou seja, com crescimento econômico sustentado de longo prazo.

O financiamento da dívida pública via emissão de títulos durante a vigência da Constituição Federal de 1946 enfrentou uma série de dificuldades, que gradativamente foram sendo superadas, mostrando a "maturidade" da questão, conforme advogou Rangel na exposição do primeiro motivo. Houve duas tentativas de lançamento de títulos de forma voluntária pelo governo a partir de meados da década de 1940, que foram frustradas por não terem tido boa aceitação junto ao público. A única emissão relevante no período foi a das subscrições compulsórias das Obrigações de Reaparelhamento Econômico, a partir de 1958. O recurso do governo à colocação de títulos de forma compulsória ilustra bem a situação difícil do crédito público no Brasil, após anos seguidos sem pagar os juros e resgatar os títulos em circulação. Entre os anos 1902 e 1956, anos em que ocorreram consolidação da dívida pública, foram autorizadas 145 emissões de títulos, com pouca ou nenhuma padronização entre eles. As taxas de juros, por exemplo, variavam de 3\% a $7 \%$ a.a. Entrementes, como já destacamos, a inflação crescente tornava insuficientes os juros pagos sobre as apólices da dívida (normalmente entre $5 \%$ e $7 \%$ ), gerando rendimentos reais negativos e reduzindo a demanda por esses títulos. $\mathrm{O}$ aumento expressivo dos déficits nominal e real (deflacionado) é mostrado nas primeiras colunas da Tabela 1. Querse, contudo, salientar que, não dispondo de mercado de títulos para financiá-lo e também incapaz de viabilizar politicamente o aumento da carga tributária, o governo financiou a quase totalidade de seus déficits via emissão de moeda, aumentando ainda mais as pressões inflacionárias (Vieira e Holland, 2008; Neto, 1980). Tal fato é ilustrado na tabela abaixo, que mostra as principais fontes de receita do período usadas para cobrir os constantes déficits orçamentários. 
Tabela 1 - Fontes de financiamento dos déficits do Governo Federal (1954-1963), em Cr\$ milhões.

\begin{tabular}{|c|c|c|c|c|c|c|c|c|c|}
\hline Anos & $\begin{array}{c}\text { Déficit } \\
\text { deflacionado } \\
(100=1954)\end{array}$ & $\begin{array}{c}\text { Variação } \\
\text { do déficit }\end{array}$ & $\begin{array}{c}\text { Emissão } \\
\text { de moeda }\end{array}$ & $\begin{array}{c}\text { Variação da } \\
\text { emissão de } \\
\text { moeda }\end{array}$ & $\begin{array}{c}\text { Colocação } \\
\text { líquida de letras } \\
\text { e obrigações }\end{array}$ & $\begin{array}{c}\text { Variação da } \\
\text { colocação de } \\
\text { letras e obrig. }\end{array}$ & Outros & $\begin{array}{c}\text { Variação } \\
\text { de outros }\end{array}$ & Inflação \\
\hline 1954 & 4,0 & - & 3,8 & - & $-2,5$ & - & 2,7 & - & - \\
\hline 1955 & 5,1 & 1,4 & 7,7 & 2,0 & 0,0 & 0,0 & $-2,0$ & $-0,7$ & 1,12 \\
\hline 1956 & 19,2 & 4,2 & 24,4 & 3,2 & 0,2 & 0,0 & $-0,7$ & 0,4 & 1,25 \\
\hline 1957 & 38,5 & 1,7 & 38,4 & 1,6 & 0,0 & 0,0 & 2,8 & $-4,0$ & 1,07 \\
\hline 1958 & 24,7 & 0,7 & 19,0 & 0,5 & 9,4 & 0,0 & 2,3 & 0,8 & 1,24 \\
\hline 1959 & 29,1 & 1,3 & 31,9 & 1,7 & 8,9 & 0,9 & $-0,3$ & $-0,1$ & 1,39 \\
\hline 1960 & 58,7 & 1,9 & 75,4 & 2,4 & 7,2 & 0,8 & $-6,0$ & 20,0 & 1,31 \\
\hline 1961 & 93,0 & 1,8 & 128,9 & 1,7 & 1,5 & 0,2 & 7,1 & $-1,2$ & 1,48 \\
\hline 1962 & 185,3 & 2,0 & 223,8 & 1,7 & 22,8 & 15,2 & 34,3 & 4,8 & 1,52 \\
\hline 1963 & 280,5 & 1,8 & 424,4 & 1,9 & 55,5 & 2,4 & 24,8 & 0,7 & 1,80 \\
\hline Acumulado & 0,0 & 126,2 & - & 111,6 & - & 5,9 & - & 9,2 & 13,63 \\
\hline
\end{tabular}

Fonte: Neto (1980), Apud. Banco Central do Brasil, Relatório de 1965, p. 222.

Devido ao agravamento do déficit ao longo do período, houve duas grandes operações de administração de passivo (ou consolidações): uma em 1956 e a outra em 1962. No ano de 1956, no início do governo JK, foi sancionada uma lei de reestruturação do serviço da Dívida Interna Federal. Esta lei tinha o objetivo de padronizar a dívida e melhorar seu controle. Tal consolidação foi influenciada por uma forte pressão de instituições financeiras que enfrentavam dificuldades em adquirir títulos em quantidade suficiente para atender aos recolhimentos compulsórios. Conforme Silva (2009), um dos principais problemas da administração da dívida encontrava-se em sua fragmentação, pois existiam em circulação mais de 130 tipos de títulos, com impressões diversas e prazos longos. Desse modo, a consolidação de 1956 agrupou todos os empréstimos em circulação em quatro graus, uniformizando o prazo de resgate para cada grau e estabelecendo novos prazos mínimos de amortização $(21,32,36$ e 68 anos, respectivamente para os graus de 1 a 4). Contudo, nesta operação de consolidação, os juros não foram uniformizados, mantendo-se vários títulos e taxas de juros diferentes. Além disso, o prazo dos novos títulos, devido às altas taxas de inflação, era considerado muito longo pelo mercado financeiro (Silva, 2009), já que implicava taxas de juros reais negativas. Em decorrência dos condicionantes apontados, a reestruturação da dívida tentada não solucionou os problemas de financiamento do governo. 
Em 1962, uma segunda operação desta natureza foi tentada. Houve um processo de consolidação mais completo, com o governo lançando os chamados Títulos de Recuperação Financeira para unificar a dívida interna da União, substituindo todos os títulos da Dívida Interna Fundada Federal, excetuadas as obrigações de Reaparelhamento Econômico. Conforme Silva (2009), estes títulos também poderiam ser emitidos para cobrir déficits orçamentários, porém, o governo não obteve êxito para esse fim, embora contasse com a necessária anuência legislativa, conforme vimos. Já a troca de títulos foi bem-sucedida, e os juros foram unificados em $7 \%$ anuais. Em virtude dessa troca, a Dívida Interna Fundada Federal ao final de 1963 era composta exclusivamente desses novos títulos (Recuperação Financeira), das Obrigações de Reaparelhamento Econômico e dos comprovantes de empréstimos compulsórios, a serem trocados no futuro por títulos. O governo João Goulart provia, assim, meios de controle mais efetivos para a administração da dívida pública federal, mas ainda não resolvia o problema das taxas de juros negativas, questão trazida por Rangel e fundamental para viabilizar o financiamento via mercado de títulos.

A segunda e terceira justificativas deixam mais clara a estratégia para lidar com os problemas de financiamento enfrentados e que - pela concessão legislativa - o governo João Goulart visava a atacar. Estas justificativas abordam conjuntamente três problemas econômicos centrais do período: fontes de financiamento para o desenvolvimento e para importação de bens de capital, constantes desvalorizações cambiais e inflação. Por um lado, as medidas propostas por Rangel visavam obter recursos oriundos da poupança privada, atendendo assim à demanda interna de crédito necessária para a manutenção e ampliação da atividade econômica; por outro lado, tais medidas também procuravam - mediante aumento do investimento interno devido ao aumento da taxa de poupança - aliviar o Balanço de Pagamentos, dentro de uma concepção desenvolvimentista de política econômica.

Conforme a proposta legislativa "em primeiro lugar, serviços básicos de infraestrutura que contam com vultuosos recursos fiscais vinculados poderão ter acesso à poupança privada como meio de obter uma antecipação de tais recursos para se habilitarem a acelerar suas obras, criar demanda (...) através do uso de capacidade ociosa, incrementar procura por mão-de-obra, (...) elevar o nível de atividade econômica do país. Em segundo lugar trata-se de orientar para o interior parte de demanda ora atendida pelo capital estrangeiro na forma de importações" (PDL 156). 
O melhor aproveitamento da capacidade ociosa, vista por Rangel como umas das causas da inflação, estava, portanto, no foco das medidas governamentais, de uma perspectiva desenvolvimentista, que buscava solucionar os problemas estruturais da economia brasileira com ajustes que induziriam o crescimento futuro. A capacidade ociosa e altos níveis de estoque constituíam mecanismos aos quais os empresários brasileiros recorriam para manter seus ativos numa forma que garantisse proteção contra a inflação, uma vez que os mecanismos financeiros eram incapazes de proporcionar esta garantia.

Por fim, a última parte do PDL 156 trata da questão das despesas, sendo elencada uma justificativa geral, explicitando a complexidade das repercussões do projeto e as dificuldades em quantificá-las. Em seu apoio, são apresentados quatro itens:

a) dado o caráter imperativo das aplicações previstas, a intervenção da poupança privada no financiamento deles corresponderá a uma redução dos encargos normais do erário;

b) dado que essas mesmas aplicações correspondem a uma elevação da taxa interna de formação de capital, resultarão em geral ativação econômica e, portanto, em elevação da renda nacional, com a consequente elevação da receita tributária;

c) dado que o mercado interno oferece capitais a taxas nominais de juros menores do que a taxa corrente de inflação, isto é, a taxa negativa de juros reais, a economia nacional beneficiar-se-á do desconto implícito nessa taxa negativa e, cumulativamente, do fato de libertar-se da taxa positiva de juros reais, implícita no financiamento externo.

d) da lei projetada não advirá qualquer despesa a ser provida por meios extraordinários.

Para a discussão do PDL 156 no Congresso Nacional, foi criada uma Comissão Especial, com relatoria do deputado federal Daniel Faraco, futuro ministro da Indústria e Comércio, sucedendo Otávio Bulhões na pasta durante o governo Castelo Branco. Tendo a Comissão manifestado que, no DCN, não foi publicada a justificativa específica para tal projeto, foi convidado o economista Ignácio Rangel, que prestou esclarecimentos à Comissão na condição de coordenador do Grupo de Trabalho que apresentou o projeto à apreciação parlamentar. 
Conforme o parecer do relator contrário à aprovação, as finalidades do projeto, no tocante à aplicação dos recursos, afiguravam-se aceitáveis. Todavia, a questão levantada pelo relator não era a da aplicação dos recursos e sim a da sua arrecadação.

Faraco argumentou que, frente à escassez de recursos que se impunha ao país, o Poder Público Federal abusava não apenas do seu poder de tributar, mas também de emitir papel-moeda. Faraco reconheceu em seu parecer o problema levantado por Rangel da negatividade da taxa de juros média no mercado. Contudo, destacou o fato de que os empréstimos de longo prazo - frequentemente concedidos por bancos oficiais - transformavam-se em verdadeiras doações para os detentores de boas relações com o governo, enquanto que os demais demandantes de crédito deveriam arcar com despesas financeiras muito mais altas para a obtenção de empréstimos.

A proposta de Rangel - conforme a transcrição do relator - era de "autorizar o Governo Federal a emitir títulos de crédito, como as Letras do Tesouro, e a revendê-los com deságio no mercado financeiro. No caso das Letras resultantes de negócios de importação - prosseguia o relator - esse deságio chegou a atingir cerca de quarenta por cento" (PDL 156). Contudo, argumentou Faraco, "o Governo Federal, recentemente, foi autorizado a emitir títulos em que a taxa real de juros ficava protegida contra os efeitos da desvalorização da moeda, de acordo com os índices que forem sugeridos pelo Conselho Nacional de Economia" (PDL 156). Entrementes, o montante autorizado - Cr\$130.000.000.000 - não havia sido lançado no mercado em razão do insucesso do Plano de Economia de Moreira Salles, como já mencionamos. ${ }^{9}$

A partir de seu arrazoado, o relator argumenta pela inadequação do novo lançamento de títulos proposto por Rangel, uma vez que, "não havendo limites para o deságio que poderiam oferecer, tais títulos entrariam com violência no leilão de recursos financeiros e as consequências disso far-se-iam sentir de forma imprevisível no financiamento das ati-

9 Cumpre observar que os propósitos do empréstimo voluntário de Moreira Salles referido pelo relator Daniel Faraco, sob o qual incidiria a correção monetária, tinha como objetivo exclusivo aumentar as receitas do governo, dentro de uma proposta mais geral de aumento de receitas e diminuição de despesas, que o banqueiro ministro havia apresentado em suas negociações com o governo norte-americano e o FMI. Para uma análise mais detalhada das metas de política econômica assumidas com o governo dos Estados Unidos pelo Brasil, conferir Loureiro, 2012, p. 228. Já a proposta de Rangel era bastante diferente em seu alcance e objetivos, pois pretendia com o instrumento da correção monetária articular e resolver problemas estruturais da economia brasileira, notadamente a insuficiência de poupança interna e os gargalos do comércio exterior. 
vidades econômicas normais". Este argumento do relator, aliás, é muito semelhante ao usado pela CNI, seis meses antes, contra o "empréstimo voluntário" de Moreira Salles. Adicionalmente, Faraco argumenta que tais títulos - que não poderiam ser de longo prazo, sob pena de o deságio praticamente inutilizá-los como captadores de recursos - viriam a agravar o déficit da União em breve prazo. Com efeito, argumenta Faraco "para resgatar os títulos que se forem vencendo, poder-se-ia utilizar o produto da venda dos novos títulos. Mas aos títulos vencidos deveriam ser pagos apenas parte desse valor devido ao deságio. Atingido o limite de emissão, o "déficit" é inescapável", pondera Faraco que a estratégia apresentada pelo PDL 156 acabaria por agravar os problemas orçamentários do governo. Desse modo, o parecer do relator foi contrário ao PDL 156.

Após a leitura do parecer do relator, foram realizadas três reuniões para elaborar o Parecer ao PDL 156, cujas atas transcritas no DCN permitem explicitar os principais argumentos em debate e relacioná-los ao contexto teórico da época. Em especial, os membros da comissão temiam que o PDL 156 pudesse causar inflação ao mesmo tempo em que - aceitando a posição do relator - desviasse recursos privados para o financiamento público, exatamente o objetivo da proposta de Rangel. Com o início dos trabalhos, o relator Daniel Faraco procede à leitura dos projetos, destacando que o maior problema do PDL 156 consistia na captação de recursos para torná-lo exequível. Nas manifestações dos membros da comissão, alguns manifestaram-se temendo o viés inflacionário do projeto, como os deputados Broca Filho e Paiva Muniz. A seguir, a palavra foi concedida a Rangel, que inicia sua exposição afirmando "a precária situação atual do mercado de títulos, ao qual nega existir em sólidas bases". Prossegue Rangel, "a empresa privada, atualmente, está vendo esgotar-se suas oportunidades de investimento. E o dinheiro, em forma de papel moeda, está perdendo em decorrência da inflação, seu valor como unidade econômica. Chegou então o momento de estruturar o mercado financeiro, objeto do Projeto de Decreto Legislativo n ${ }^{\circ} 156$ ". Após a manifestação de Rangel, iniciou-se a discussão da proposta legislativa pelos parlamentares membros da Comissão Especial designada para apreciar a matéria: 
Iniciado o debate em torno da viabilidade ou não do projeto em pauta, trocam pontos de vista os senhores Adolfo Gentil, Pacheco Chaves, Herbert Levy, Broca Filho, Paiva Muniz, Daniel Faraco, Leite Neto e o senhor Presidente. O senhor Herbert Levy manifesta-se contrário, frontalmente, à delegação de poderes; o senhor Broca Filho manifesta receio de se fomentar a inflação e ao mesmo tempo se inflacionar o mercado de títulos; o senhor Leite Neto admite em princípio que apoiaria a delegação de poderes se encontrasse no projeto mais vantagens que desvantagens; o senhor Paiva Muniz, à margem das declarações dos Senhores Broca Filho e Leite Neto, que consideraram a inflação a causa maior do processo espoliativo que está empobrecendo as classe média e operária, afirmou que o déficit orçamentário, este sim, é responsável em grande parte pela atual situação financeira. Mas a responsabilidade não era apenas do Poder Executivo, mas do Congresso Nacional. O senhor Sérgio Magalhães admite que o receio do Senhor Daniel Faraco, quanto à inexistência de recursos pareça-lhe infundado, uma vez que em período inflacionário há lucros excessivos. Esses lucros é que não estão sendo devidamente encaminhados.

O senhor Presidente, com a palavra, observa que o PDL 156 não veio devidamente acobertado da obrigatoriedade jurídica referida no art. 29 da legislação complementar ao Ato Adicional $n^{\circ} 4$. A seguir alude à questão das emendas que devem ser apresentadas à Comissão. Devido ao adiantado da hora, agradeceu ao senhor Ignácio Rangel a exposição sobre o Projeto em pauta...

A ata do turno da tarde não foi publicada no DCN. Já a ata da votação, realizada no turno da noite, pontua algumas questões, especialmente que os deputados não conseguem ver o viés anti-inflacionário do PDL 156. Os deputados da oposição aconselham o governo a criar um plano de redução de gastos caso queira debelar a inflação. Após essas discussões, o Projeto foi à votação, tendo sido rejeitado por cinco votos contra dois. 


\section{Os mecanismos de correção monetária no PAEG}

O PAEG constituiu um amplo conjunto de medidas econômicas com as quais o governo Castelo Branco pretendia tirar o país da crise econômica. Entre suas novidades, destaca-se a institucionalização de mecanismos de correção monetária no arcabouço institucional brasileiro. Mas o PAEG alterava de forma substantiva os objetivos desses mecanismos quando comparados com os objetivos do PDL 156. Dois objetivos básicos são transparentes com a proclamação da Lei 4.357/1964 de Bulhões. O primeiro consiste na criação de um Fundo das Indenizações Trabalhistas, reajustáveis em Obrigações Reajustáveis do Tesouro Nacional (ORTN). O segundo consiste em reajustar pela ORTN o ativo imobilizado das pessoas jurídicas. Os reajustes de ORTN, assim como na proposta de Rangel, que diferia daquela por prever descontos de face, devem ter seus coeficientes calculados pelo Conselho Nacional de Economia. Estavam excluídas na nova lei as concessionárias de energia elétrica, as sociedades de economia mista com participação majoritária da União, Estados e Municípios e as empresas com capital social menor do que 50 salários mínimos fiscais. Os projetos da Superintendência para Valorização da Amazônia (SPVA) e da Superintendência de Desenvolvimento do Nordeste (SUDENE) também estavam isentos conforme a nova lei. ${ }^{10}$

De uma maneira geral, cumpre destacar a compulsoriedade do empréstimo oriundo dos rendimentos do trabalho prevista nos Artigos $18^{\circ} \mathrm{e}$ $19^{\circ}$, que mostra o caráter arbitrário e autoritário da nova legislação, (bem como a mudança de ênfase com relação às tentativas anteriores de criação de fundos compulsórios, como no Plano Econômico de Moreira Salles, que previa aplicação de um empréstimo compulsório no Imposto de Renda a ser pago pelos empresários), de modo que o aparente benefí-

\footnotetext{
${ }^{10}$ A Lei 4.357/1964 estabelecia o cálculo das quotas de depreciação ou amortização de bens móveis $\left(\right.$ Art. $6^{\circ}$ ), o reajuste monetário de débitos fiscais $\left(\right.$ Art. $\left.7^{\circ}\right)$, o reajuste monetário de débitos previdenciários e de assistência social para pessoas físicas e jurídicas $\left(A r t .8^{\circ}\right)$, a correção monetária das multas fiscais (Art. $9^{\circ}$ ) e o vencimento das dívidas fiscais (Art. $10^{\circ}$ ). Em seu Art. $11^{\circ}$ a Lei previa o crime de apropriação indébita para o contribuinte que não recolhesse os impostos corrigidos, a tributação na fonte com os valores corrigidos pela correção monetária $\left(\operatorname{Art} .12^{\circ}\right.$ ), os cálculos de reajuste do IR (Art. 13 ${ }^{\circ}$ ), o abatimento da renda bruta para efeitos de cálculo do IR $\left(\right.$ Art. $\left.1^{\circ}\right)$. O restante da Lei apresenta uma série de providências amplamente relacionadas ao mercado de trabalho, como o Art. $16^{\circ}$, referente à equiparação fiscal de Trabalhador Avulso e Trabalhador Assalariado, o Art. $17^{\circ}$ referente às mudanças de critério de classificação para juros de debêntures ou outras obrigações ao portador, os Artigos $18^{\circ}$ e $19^{\circ}$, que estabelecem o empréstimo compulsório sobre os rendimentos do trabalho - desconto na fonte, o Art. $27^{\circ}$ que trata da alteração no cálculo do IR adicional em relação ao capital das pessoas jurídicas e o Art. $28^{\circ}$ que trata dos casos que desobrigam o contribuinte a apresentar a declaração de IRPF.
} 
cio da indexação do fundo salarial é contrabalançado com uma política salarial recessiva, uma vez que os reajustes salariais não acompanharam a inflação do período. A partir dessa visão panorâmica é possível visualizar claramente os objetivos fiscais e arrecadatórios do PAEG, que, ao mesmo tempo em que estruturava o mercado de trabalho a partir de novos mecanismos de correção monetária, protegendo de certa forma os interesses dos trabalhadores, por outro lado, promovia arrocho e estabelecia normas compulsórias sobre os rendimentos do trabalho que visavam ao aumento das receitas fiscais. Neste sentido, é possível alinhar o PAEG às propostas ortodoxas de gestão da política econômica, uma vez que pretendia fazer um ajuste fiscal mediante redução de despesas e aumento da arrecadação, sendo o principal ajuste no mercado de trabalho, em detrimento dos rendimentos dos trabalhadores.

Já o PDL 156 de Ignácio Rangel propunha outro desenho dos mecanismos de correção monetária para uma economia que encontrava - segundo seu autor - seu principal desafio no desenvolvimento sustentado de longo prazo. Para tanto, como vimos, o fundo proposto por Rangel buscava atacar, de forma articulada, mediante a organização dos capitais privados, problemas de estrangulamento externo, baixos níveis de poupança e de investimento e desorganização (praticamente inexistência) do mercado de crédito doméstico.

\section{Considerações finais}

A correção monetária faz parte de um conjunto de medidas institucionais introduzidas no período do ministro Bulhões, as quais contribuem para explicar o forte crescimento dos anos seguintes, conhecido como "milagre brasileiro". Até meados da década de 1980, quando foi associada à inércia inflacionária e, portanto, como um dos fatores a realimentar a inflação, foi louvada e enaltecida. Contudo, a correção monetária trouxe consequências não previstas e não desejáveis para a economia brasileira: a inflação inercial que assolaria o país entre 1980 e 1994. Ela aconteceu devido à indexação formal e informal da economia, a qual, por sua vez, decorreu da prática, generalizada entre os agentes econômicos, de corrigir os preços por índices verificados na inflação passada. Desta maneira, a correção monetária, de heroína nos anos 1960 e 1970, passou a ser vista como vilã nos anos 1980 e 1990. Contudo, em 
princípio, o próprio Friedman mostrar-se-ia empolgado com sua criação: "Friedman visitou o Brasil em 1973 e apaixonou-se pela nossa correção monetária. Num artigo publicado em 1974, recomendou a ampla indexação como remédio para abreviar os efeitos colaterais do combate à inflação. Em síntese, a indexação apagaria a memória inflacionária, tornando praticamente vertical a curva de Phillips a curto prazo" (Simonsen e Cysne, 1989, p. 447).

Longo tempo após os fatos analisados neste artigo, Rangel ainda manifestava-se inconformado com a rejeição de seu projeto de decreto legislativo. Era frequente sua menção entre amigos e colegas de profissão ao fato de que o projeto proposto havia sido incorporado pela área econômica dos governos militares, sem que se tivessem dado os devidos créditos ao seu autor. Assim, confirma Saturnino Braga, seu colega no BNDE, que testemunha sua inconformidade com o fato, em entrevista por e-mail aos autores em 2016: "O BNDE era pequeno e os seus técnicos conversavam bastante entre si. E Rangel era das vozes mais escutadas pelos jovens benedenses. (...) Ele almoçava num restaurante perto do Banco, na rua da Quitanda, o 'Chave de Ouro', frequentemente com Domar Campos, outro economista que não era do Banco mas era amigo dele. E me lembro bem de que Rangel, antes de 64 , no período João Goulart, recomendava a emissão de títulos públicos para financiar investimentos em infraestrutura e, como a inflação estava muito alta, dizia que esses títulos deviam ter o seu valor corrigido anualmente, pela taxa da inflação, para ser honesto com os investidores". Também conforme depoimento por e-mail de Bresser-Pereira aos autores em 2015, Rangel "falou, mais de uma vez, sobre a precedência dele na aplicação da indexação em títulos públicos. E numa ocasião, em 1964, no aeroporto Santos Dumont, encontrou-se com Octávio Bulhões, então já Ministro da Fazenda, e o lembrou que isso era uma ideia dele". Deve-se lembrar que o Congresso que rejeitara o projeto de Rangel foi praticamente o mesmo que saudou o de Bulhões, pois não houve eleição legislativa entre ambos. Entretanto, deve-se lembrar a alteração substantiva das condições políticas neste curto período de tempo, com o fim do período democrático instaurado desde 1946 e o início da ditadura civil-militar em abril de 1964.

Contava Rangel, também, que, em certa feita, cobrara a incoerência de um deputado que votara contra seu projeto, mas pouco tempo depois aprovara a proposta encaminhada por Bulhões. Este teria respondido que não era nada pessoal contra ele, mas questão fundamentalmente 
política: em 1962, a conspiração contra Goulart já estava em marcha, e ele e seus colegas não estavam dispostos a conceder ao governo um instrumento muito bom, que poderia ajudar a salvá-lo. Rangel costumava falar do fato ocorrido em palestras, e uma das poucas vezes que se referiu por escrito ao assunto foi em artigo de 1985, publicado na Revista de Economia Política:

Esse projeto (Decreto Legislativo $n^{\circ} 156-A-$ 1962) propunha o lançamento de títulos destinados a captar para o Tesouro o diferencial de valor representado pela negatividade da taxa real de juros. Eventualmente, dito projeto foi rejeitado, pelo óbvio motivo de que a maioria dos deputados componentes da Sessão da Comissão Especial $n^{\circ} 7$, da referida Câmara, não desejava ver fortalecido o governo João Goulart; mas, uma vez deposto esse governo, o motivo do projeto foi retomado e, como esperavam os inspiradores deste, com resultados muito brilhantes, pois a eles não é estranho o desempenho da economia nacional, no período coberto, quando o PIB e a Produção Industrial cresceram cerca de 8,1 por cento ao ano (1963-80). Não há comparação possível entre o lançamento de títulos proposto por aquele projeto - 200 bilhões de velhos cruzeiros ou 200 milhões de cruzeiros novos, no valor, de 1980, de perto de 50 bilhões de cruzeiros - e as muitas dezenas de trilhões da divida interna governamental desse mesmo ano. Noutros termos, os inspiradores do projeto não se haviam equivocado, nem quanto à potencialidade do mercado, nem quanto aos efeitos que de sua exploração deviam ser esperados.

Finalmente, é importante destacar que o caso de Rangel ajuda a mostrar que as ideias econômicas estão umbilicalmente ligadas às condições políticas e históricas, as quais constituem o solo no qual elas podem florescer. O seu diagnóstico da inflação brasileira constituiu uma análise lúcida e pertinente da realidade econômica do período, que, quiçá, poderia ter contribuído para viabilizar economicamente o frágil governo de João Goulart. Se as ideias econômicas fossem aceitas somente pelo seu mérito em abstrato, a proposta de Rangel certamente figuraria entre as grandes contribuições do pensamento econômico brasileiro aplicadas 
à solução dos problemas econômicos reais. $\mathrm{O}$ reconhecimento de sua contribuição aos problemas inflacionários brasileiros aponta, sobretudo, para a reparação de uma injustiça histórica.

\section{Referências}

\section{- Fontes primárias}

Bresser-Pereira, Luiz Carlos. Entrevista aos autores, 2015.

CONGRESSO NACIONAL. Projeto de Decreto Legislativo $156^{a} .1962$.

Saturnino Braga, Roberto. Entrevista aos autores, 2016.

\section{- Livros e Artigos}

BANDEIRA, Moniz. O Governo João Goulart: as Lutas Sociais no Brasil, 1961-1964. Rio de Janeiro, Civilização brasileira, 1977.

BARBOSA, Fernando de Holanda. Curva de Phillips e o modelo de realimentação: será Friedman um neoestruturalista? Texto para Discussão Interna $n^{\circ}$ 5. Rio de Janeiro: INPES/IPEA, 1979.

. A inflação brasileira no pós-guerra: monetarismo versus estruturalismo. Rio de Janeiro: IPEA/ INPES, 1983.

. Ensaios sobre inflação e indexação. FGV, 1987.

. Contribuição acadêmica de Mário Henrique Simonsen. Revista de Econometria, v. 17(1), 1997.

BIELSCHOWSKY, Ricardo. Pensamento econômico brasileiro: o ciclo ideológico do desenvolvimentismo. 5. ed. Rio de Janeiro: Contraponto, 2004.

BRESSER-PEREIRA, L. C. Prefácio. In: Rangel, Ignácio. A inflação brasileira. 5. ed. São Paulo: Brasiliense, 1978.

BRESSER-PEREIRA, L. C.; Rego, J. C. Um mestre da economia brasileira: Ignácio Rangel. Revista de Economia Política, vol. 13, n. 2 (50), abr.-jun, 1993.

CASTELO BRANCO, Carlos. Introdução à evolução de 1964. Rio de janeiro, Artenova, 1977.

FARO, Luiz Cesar e Sinelli, Mônica. Ignácio Rangel. Rio de Janeiro: Insight, 2014.

FERREIRA, Jorge e Gomes, Angela de Castro. 1964: o golpe que Derrubou um Presidente. Rio de Janeiro, Civilização Brasileira, 2014

FERREIRA, Marieta de Moraes (org. ). João Goulart: entre a Memória e a História. Rio de Janeiro, Editora FGV, 2006.

FGV. "25 anos de economia brasileira - estatísticas básicas”. In: Conjuntura Econômica. Rio de Janeiro, v. $26,1972$.

FICO, Carlos. "Versões e controvérsias sobre 1964 e a ditadura militar". In: Revista Brasileira de História. São Paulo, v. 24, nº 47: 29 - 60, 2004.

FONSECA, P. C. D. "Legitimidade e Credibilidade: Impasses da Política Econômica do Governo Goulart". In: Estudos Econômicos, São Paulo, USP, v. 34, n. 1(93): 587 - 622, 2004.

FONSECA, Pedro C. D. e Monteiro, Sérgio M. "Credibilidade e Populismo: a Política Econômica dos Governos Vargas e Goulart”. Revista Brasileira de Economia. Rio de Janeiro, 59(2), abr/jun: 215 - 243, 2005.

FRIEDMAN, M. Monetary Correction. In: Essays on Inflation and Indexation. Washington: American Enterprise Institute, 1974. 
FURTADO, C. Industrialização e inflação. In: Economia brasileira, jul.-dez., 1960.

GUDIN, Eugênio e Simonsen, Roberto C. A controvérsia do planejamento na economia brasileira. Rio de Janeiro: IPEA/INPES, 2 ed., 1978.

IANNI, Octávio. Estado e Planejamento Econômico no Brasil: 1930/70. Rio de Janeiro: Civilização Brasileira, 1977.

IBGE. Estatísticas históricas do Brasil. Rio de Janeiro, 1987.

. Estatísticas históricas do Brasil. Séries Econômicas, Demográficas e Sociais. 1550 a 1988. 2. ed. Rio de Janeiro, 1990.

LOPES, F. L. Teoria e política de inflação brasileira: uma revisão critica da literatura. In: Sayad, João. Resenhas de economia brasileira. São Paulo: Saraiva, 1979.

LOUREIRO, Felipe Pereira. Empresários, Trabalhadores e Grupos de Interesse: a Política Econômica nos Governos Jânio Quadros e João Goulart, 1961-1964, IFCHL/USP (Tese de Doutorado), 2012.

MARTONE, Celso. Análise do Plano de Ação Econômica do Governo (PAEG) (1964-1967). In: LAFER, Betty Mindlin (org.). Planejamento no Brasil. São Paulo: Perspectiva, 1975.

MODENESI, André de Melo. Regimes monetários: teoria e a experiência do real. Barueri: Manole, 2005.

MORAES, Bernardo Ribeiro. The monetary correction of tax debts within the framework of Brazilian Law. In: Monetary Indexation in Brazil. Amsterdam: International Bureau of Fiscal Documentation, 1983.

MOREIRA, Cassio S. O Projeto de Nação do Governo João Goulart: o Plano Trienal e as Reformas de Base (1961-1964). PPGE/UFRGS (Tese de Doutorado), 2011.

MUNTEAL, Oswaldo et al. (org.). O Brasil de João Goulart; um projeto de Nação. Rio de Janeiro: PUC/ Rio: Contraponto, 2006.

NETO, A. L. da S. Dívida pública interna federal: uma análise histórica e institucional do caso brasileiro. Brasília: UnB, 1980.

NOYOLA, J. Inflación y desarrollo económico en Chile y México. Panorama Económico, v. 11(170), 1957.

OLIVEIRA, J. La inflación estructural y el estructuralismo latinoamericano. In. Sunkel, O. et. al. Inflación y estructura económica. Buenos Aires: Paidós, 1963.

PINTO, A. Ni estabilidad ni desarrollo, la política del Fondo Monetario. Santiago do Chile: Editorial Universitaria, 1958.

.El análisis de la inflación: estructuralistas y monetaristas; un recuento. Economía, Facultad de Ciencias Económicas, Universidad de Chile, segundo trimestre, 1963.

PREBISCH, R. El falso dilema entre desarrollo económico y estabilidad monetaria. Boletín Económico de América Latina, v. 6(1), 1961.

. El desarrollo económico de la América Latina y algunos de sus principales problemas. Boletín Económico de América Latina, v. 7(1), 1962.

RANGEL, Ignácio. A inflação brasileira. Rio de Janeiro: Tempo Brasileiro, 1963. . Ignácio Rangel; obras reunidas. Rio de Janeiro, Contraponto, 2005.

. Recessão, inflação e dívida interna. Revista de Economia Política, vol. 5(3), jul.-set., 1985.

. Ciclo, tecnologia e crescimento. Rio de Janeiro, Civilização Brasileira, 1982.

RESENDE, André Lara. Estabilização e reforma: 1964-1967. In: ABREU, Marcelo de Paiva (org.). A Ordem do progresso: cem anos de política econômica republicana: 1889-1989. Rio de janeiro: Campus, 1989.

SILVA, Anderson Caputo. Origem e história da dívida pública no Brasil até 1963. In: Silva, A. C.; Carvalho, L. O.; Medeiros, O. L. (Orgs.). Dívida pública: a experiência brasileira. Secretaria do Tesouro Nacional, Banco Mundial, 2009.

SIMONSEN, Mario Henrique. Inflação: gradualismo X tratamento de choque. Rio de Janeiro: APEC, 1970.

SIMONSEN, Mario Henrique e Cysne, Rubens Penha. Macroeconomia. Rio de Janeiro: Ao livro Técnico, 1989.

Estud. Econ., São Paulo, vol.47, n.2, p.429-458, abr.-jun. 2017 
SUNKEL, O. La inflación chilena: un enfoque heterodoxo. El trimestre económico, vol. 25(4), 1958.

. Un esquema general para el análisis de la inflación. Economía, n. 62, Facultad de Ciencias Económicas, Universidad de Chile, 1959.

TILBERY, Henry. Indexation in the Brazilian taxation system. In: Monetary Indexation in Brazil. Amsterdam: International Bureau of Fiscal Documentation, 1983.

VIEIRA, Fabrício de Assis e Holland, Márcio. Crescimento econômico secular no Brasil, modelo de Thirlwall e termos de troca. Economia e sociedade, v. 17(2): 17 - 46, 2008. 